$\begin{array}{ll}\text { Volume } & : 05 \\ \text { Nomor } & : 02 \\ \text { Bulan } & : \text { Mei } \\ \text { Tahun } & : 2019 \\ \text { http } & : / / \text { ejurnal.pps.ung.ac.id/index.php/AKSARA/index }\end{array}$

\title{
PENERAPAN MODEL PEMBELAJARAN PKBP (PENDIDIKAN KEWIRAUSAHAAN BERBASIS PENGALAMAN) DALAM MENINGKATKAN MINAT BELAJAR BISNIS
}

\author{
Batsir Podungge \\ batsirpodungge@gmail.com
}

Received: 29 Februari 2019; Revised: 12 April 2019; Accepted: 15 April 2019

\begin{abstract}
Learning model that not only provides insight into the knowledge of concepts only. However, it also provides a real experience that will build skills through a real assignment of entrepreneurship. The result of this research is after applying the Learning Model PKBP (Experience-Based Entrepreneurship Education), students' interest in business learning can increase. While on the second cycle consisting of planning, observation, and reflection action. In this second cycle, the implementation of learning model of PKBP (Experience-Based Entrepreneurship Education), similar to that applied in cycle I, there is only slight difference in this cycle 2 on teaching materials. And the results of the learning model that has been implemented shows an increase in Student Learning Interest of Class XII ATR SMK Negeri Model Gorontalo Tahun Teaching 2016/2017.
\end{abstract}

KeyWords: Learning Experience-Based Entrepreneurship Education

\begin{abstract}
ABSTRAK
Salah satu model pembelajaran berbisnis yang sering dilaksanakan oleh siswa SMK Negeri Model Gorontalo adalah model pembelajaran PKBP (pendidikan kewirausahaan berbasis pengalaman). Model pembelajaran PKBP ini adalah model pembelajaran yang tidak hanya memberikan wawasan pengetahuan konsep-konsep saja. Namun, juga memberikan pengalaman yang nyata yang akan membangun keterampilan melalui penugasan nyata tentang wirausaha. Selanjutnya, metode ini akan mengakomodasi dan memberikan proses umpan balik serta evaluasi antara hasil penerapan dengan apa yang seharusnya dilakukan. Pada model pembelajaran PKBP (pendidikan kewirausahaan berbasis pengalaman) seringkali siswa di hadapkan pada kondisi nyata untuk melaksanakan sebuah wirausaha atau bisnis, sehingga siswa dapat belajar dari pengalaman yang di perolehnya sendiri. Oleh karenanya dengan model pembelajaran seperti ini diasumsikan dapat meningkatkan minat belajar bisnis siswa SMK Negeri Model Gorontalo. Permasalahan yang di angkat dalam PTK ini adalah "Penerapan Model Pembelajaran PKBP (Pendidikan Kewirausahaan Berbasis Pengalaman) Dalam Meningkatkan Minat Belajar Bisnis Siswa Kelas XII ATR SMK Negeri Model Gorontalo Tahun Ajaran 2016/2017" .Hasil ahir dari penelitian ini adalah setelah menerapkan Model Pembelajaran PKBP (Pendidikan Kewirausahaan Berbasis Pengalaman), minat siswa dalam belajar bisnis dapat meningkat. Sedangkan Pada siklus ke II yang terdiri dari kegiatan perencanaan, pengamatan, dan refleksi tindakan. Pada siklus II ini pelaksanaan model pembelajaran PKBP (Pendidikan Kewirausahaan Berbasis Pengalaman), juga sama seperti yang di terapkan pada siklus I, hanya ada perbedaan sedikit pada siklus 2 ini pada materi ajar. Dan hasil dari model pembelajaran yang sudah di laksanakan menunjukkan
\end{abstract}




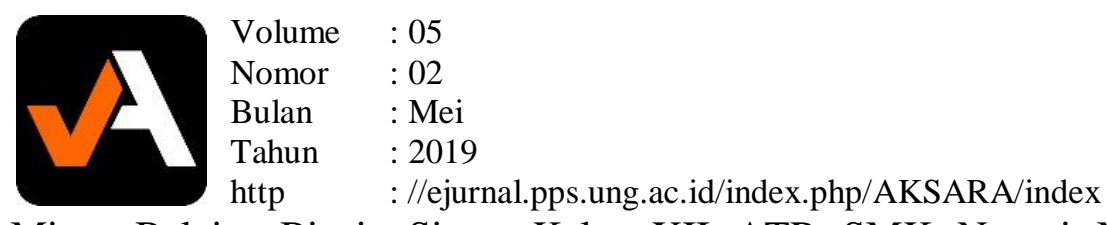

adanya peningkatan Minat Belajar Bisnis Siswa Kelas XII ATR SMK Negeri Model Gorontalo Tahun Ajaran 2016/2017

\section{PENDAHULUAN}

Salah satu model pembelajaran berbisnis yang sering dilaksanakan oleh siswa SMK Negeri Model Gorontalo adalah model pembelajaran PKBP (pendidikan kewirausahaan berbasis pengalaman). Model pembelajaran PKBP ini adalah model pembelajaran yang tidak hanya memberikan wawasan pengetahuan konsep-konsep saja. Namun, juga memberikan pengalaman yang nyata yang akan membangun keterampilan melalui penugasan nyata tentang wirausaha. Selanjutnya, metode ini akan mengakomodasi dan memberikan proses umpan balik serta evaluasi antara hasil penerapan dengan apa yang seharusnya dilakukan. Pada model pembelajaran PKBP (pendidikan kewirausahaan berbasis pengalaman) seringkali siswa di hadapkan pada kondisi nyata untuk melaksanakan sebuah wirausaha atau bisnis, sehingga siswa dapat belajar dari pengalaman yang di perolehnya sendiri. Oleh karenanya dengan model pembelajaran seperti ini diasumsikan dapat meningkatkan minat belajar bisnis siswa SMK Negeri Model Gorontalo.

Minat belajar diartikan sebagai kecenderungan seseorang yang berasal dari luar maupun dalam sanubari yang mendorongnya untuk merasa tertarik terhadap suatu hal sehingga mengarahkan perbuatannya kepada suatu hal tersebut dan menimbulkan perasaan senang. Sedangkan bisnis adalah sebuah kegiatan yang mendapatkan penghasilan. Jadi minat belajar bisnis adalah ketertarikan untuk mempelajari dan mendalami kegiatan yang mendapatkan penghasilan.

Berdasarkan penjelasan di atas maka guru yang disini berperan sebagai peneliti hendak melakukan kajian lebih mendalam dalam sebuah Penelitian Tindakan Kelas (PTK) yang berjudul "Penerapan Model Pembelajaran PKBP (Pendidikan Kewirausahaan Berbasis Pengalaman) Dalam Meningkatkan Minat Belajar Bisnis Siswa Kelas XII ATR SMK Negeri Model Gorontalo Tahun Ajaran 2016/2017.”

\section{TINJAUAN PUSTAKA}

\section{Model Pembelajaran Pkbp (Pendidikan Kewirausahaan Berbasis Pengalaman)}

Istilah model pembelajaran sangat dekat dengan pengertian strategi pembelajaran dan dibedakan dari istilah strategi, pendekatan dan metode pembelajaran. Istilah model pembelajaran mempunyai makna yang lebih luas daripada suatu strategi, metode, dan teknik. Sedangkan istilah "strategi" awal mulanya dikenal dalam dunia militer terutama terkait dengan perang atau dunia olah raga, namun demikian makna tersebut meluas tidak hanya ada pada dunia militer atau olahraga saja akan tetapi bidang ekonomi, sosial, pendidikan.

PKBP (Pendidikan Kewirausahaan Berbasis Pengalaman)

Beberapa puluhan tahun yang lalu, ada pendapat yang mengatakan bahwa kewirausahaan tidak dapat diajarkan. Akan tetapi sekarang ini Enterpreneurship (kewirausahaan) merupakan mata pelajaran yang dapat diajarkan di sekolah-sekolah dan telah bertumbuh sangat pesat.

Transformasi pengetahuan kewirausahaan telah berkembang pada akhir-akhir ini. Demikian pula di negara kita pengetahuan kewirausahaan diajarkan di sekolah dasar, sekolah menengah, perguruan tinggi di berbagai kursus bisnis. Jadi kesimpulannya kewirausahaan itu dapat diajarkan. Berikanlah para siswa penanaman sikap-sikap perilaku untuk membuka bisnis kemudian kita akan membuat mereka menjadi seorang wirausaha yang berbakat (Buchari Alma 2000:5).

\section{METODE PENELITIAN}

90 AKSARA Jurnal Ilmu Pendidikan Nonformal 


$\begin{array}{ll}\text { Volume } & : 05 \\ \text { Nomor } & : 02 \\ \text { Bulan } & : \text { Mei } \\ \text { Tahun } & : 2019 \\ \text { http } & : \text { //ejurnal.pps.ung.ac.id/index.php/AKSARA/index }\end{array}$

Pokok bahasan dalam Penelitian Tindakan Kelas (PTK) ini adalah penerapan model pembelajaran pkbp (pendidikan kewirausahaan berbasis pengalaman) dalam meningkatkan minat belajar bisnis siswa kelas XII ATR SMK Negeri Model Gorontalo Tahun Ajaran 2016/2017. Jadi, Penelitian tindakan kelas (PTK) ini dilaksanakan di kelas XII ATR SMK Negeri Model Gorontalo dengan jumlah peserta didik 27 siswa.

Adapun rancangan yang digunakan dalam penelitian ini adalah menggunakan Penelitian Tindakan Kelas (Classromm Activity Research). Pelaksanaan tindakan dalam PTK meliputi empat alur (langkah): (1) perencanaan tindakan; (2) pelaksanaan tindakan; (3) Pengamatan; (4) refleksi.

Teknik analisis data yang digunakan secara deskreptif yaitu hanya mengumpulkan data yang diperoleh melalui pengamatan dan tes hasil belajar di susun, dijelaskan, dan akhirnya di analisis dalam tiga tahapan yaitu:

1. Reduksi Data

Reduksi data merupakan suatu proses pemilihan, pemusatan dan perbaikan pada penyederhanaan data. Pada tahap reduksi data pengamatan terhadap proses pembelajaran kewirausahaan dalam meningkatkan minat belajar bisnis.

2. Display Data (Penyajian Data)

Data yang diperoleh melalui pengamatan dan tes hasil belajar berbentuk tabel dan kalimat sederhana setiap putaran.

Tujuan penelitian tindakan kelas yang di lakukan pada siswa kelas XII ATR SMK Negeri Model Gorontalo tahun ajaran 2016/2017 adalah untuk meningkatkan minat belajar bisnis siswa melalui model pembelajaran PKBP (Pendidikan Kewirausahaan Berbasis Pengalaman). Maka, yang menjadi indikator kinerja dalam penelitian ini adalah model pembelajaran PKBP (Pendidikan Kewirausahaan Berbasis Pengalaman) dapat menjadi model pembelajaran yang efektif kepada siswa dalam meningkatkan minat belajar bisnis siswa.Untuk mengukur keberhasilan penelitian ini, maka indikator kinerja berikutnya apabila hasil penelitian ini dengan valid dapat menunjukkan:

a. Sekurang-kurangnya $65 \%$ siswa mampu meningkatkan minatnya untuk belajar berbisnis.

b. Terjadi kondusifitas pembelajaran pendidikan kewirausahaan

c. Kesesuaian metode pembelajaran dengan materi yang di ajarkan.

\section{HASIL PENELITIAN DAN PEMBAHASAN}

Subjek penelitian disini adalah seluruh siswa kelas XII ATR SMK Negeri Model Gorontalo tahun ajaran 2016/2017. Berikut adalah data nama-nama siswa kelas XII ATR SMK Negeri Model Gorontalo tahun ajaran 2016/2017

Peneliti mulai melaksanakan kegiatan penelitian yang pertama pada tanggal 10 September 2016 dengan mengadakan pembelajaran pendidikan kewirausahaan pada aspek meningkatkan minat belajar bisnis dengan metode yang biasa di lakukan yaitu metode konvensional (ceramah kemudian praktek). Kegiatan pra siklus ini bertujuan untuk mengetahui kemampuan dan minat awal yang dimiliki oleh siswa dalam belajar bisnis sebelum diterapkan Model Pembelajaran PKBP (Pendidikan Kewirausahaan Berbasis Pengalaman).

Hasil dari refleksi pada siklus ini adalah meskipun masih terdapat beberapa kesulitan yang dihadapi oleh siswa dalam mengikuti pembelajaran dengan model pembelajaran PKBP (Pendidikan Kewirausahaan Berbasis Pengalaman), akan tetapi penerapan model 


$$
\begin{array}{ll}
\text { Volume } & : 05 \\
\text { Nomor } & : 02 \\
\text { Bulan } & : \text { Mei } \\
\text { Tahun } & : 2019 \\
\text { http } & : / / \text { ejurnal.pps.ung.ac.id/index.php/AKSARA/index }
\end{array}
$$

pembelajaran PKBP (Pendidikan Kewirausahaan Berbasis Pengalaman) pada siklus I ini berjalan dengan cukup baik. Hal ini terlihat pada antusiasme yang ditunjukkan oleh siswa dalam mengikuti pembelajaran serta penguasaan meteri.

Dengan menggunakan Model Pembelajaran PKBP (Pendidikan Kewirausahaan Berbasis Pengalaman) pembelajaran meresensi buku dapat kondusif. Berikut adalah data hasil belajar siswa dalam meresensi buku pada siklus I.

Penerapan Model Pembelajaran PKBP (Pendidikan Kewirausahaan Berbasis Pengalaman) banyak menuntut peran aktif siswa baik dalam kerja kelompok maupun yang bersifat individu. Hal ini dibuktikan dengan perolehan hasil belajar siswa yang mengalami peningkatan dimulai dari pelaksanaan pra siklus sampai pada siklus II.

\section{PENUTUP}

Pada proses pelaksanaan siklus ke-1 siswa diminta untuk mengikuti KBM dengan Model Pembelajaran PKBP (Pendidikan Kewirausahaan Berbasis Pengalaman). Dengan Model Pembelajaran PKBP (Pendidikan Kewirausahaan Berbasis Pengalaman) yang mengaktifkan pembelajar untuk membangun pengetahuan dan keterampilannya dalam mencipatakan dan menjalalankan sebuah bisnis melalui pengalamannya secara langsung maka siswa lebih semangat dan antusias dalam mengikuti arahan dari guru untuk belajar bisnis.

Penelitian tindakan kelas ini dilakukan dalam 2 siklus. Siklus kedua ini adalah siklus yang merupakan refleksi dari siklus pertama. Pada siklus ke II ini terdiri dari kegiatan perencanaan, pengamatan, dan refleksi tindakan.Pada siklus ini pelaksanaan model pembelajaran PKBP (Pendidikan Kewirausahaan Berbasis Pengalaman) juga tidak sama persis seperti yang di terapkan pada siklus I, ada tambahan materi yang di sampaikan guru dalam siklus 2 ini. Dan hasil dari model pembelajaran PKBP (Pendidikan Kewirausahaan Berbasis Pengalaman) yang sudah di laksanakan menunjukkan adanya peningkatan minat belajar bisnis pada siswa kelas XII ATR SMK Negeri Model Gorontalo Tahun Ajaran 2016- 2017.

\section{DAFTAR PUSTAKA}

Arsyad, Azhar. 2011. Media Pembelajaran. Jakarta: Rajagrafindo

Alfabeta. Hamalik, Oemar. 1982. Media Pendidikan. Bandung: Alumni.

Budiningsih, C. Asri, DR. 2005. Belajar dan Pembelajaran. Jakarta: Rineka Cipta

Dadan. 2014. Pengertian Pendekatan. [online]. Tersedia :http://dadangjsn.blogspot.com/2014/06/pengertiandefinisi-pendekatan-saintifik.html 13.48. (20 April 2015)

Djaelani. 2014. Definisi model pembelajaran. [online]. Tersedia: http://djaelanicilukba.blogspot.com/2014/01/definisi-model-pembelajaranmenurut.html 13.45. (20 april 2015)

DH Basu Swastha DR.1998. Pengantar Bisnis Modern. Liberty:Yogyakarta

Eka. 2014. Model Pembelajaran. [online]. Tersedia :http://www.ekaikhsanudin.net/2014/12/pembelajaran-model-discovery-learning.html 13.53. (20 April 2015) 